\title{
DON'T TOUCH THE WATER! POLLUTION AND THE FUTURE OF CHINESE AGRICULTURE Luigi Tomba
}

\section{$\mathrm{I}$}

S FARMING STILL WHAT Chinese peasants do? In most of the countryside, the income generated by farming remains far below what can be earned in even low-paid industrial or services jobs in the cities. For rural youth, the simplest path to social mobility continues to be migration to industrial areas.

For the people who stay, often the elderly or those with limited skills, few are willing to invest their savings in farms that are held on thirty-year leases on collectively-owned land and generally produce meagre incomes. Even the high-risk gamble of the stock market is more likely to appeal to farmers than the purchase of next-generation tractors. During 2014 and 2015, when the Chinese stock market was most bullish, many villagers diverted cash and time from farming to the dazzling experience of betting on China's 'red chips'. Excluded from the urban real estate market that in two decades had turned many urban employees into a new propertied middle class, many farmers blithely disregarded the risks of stock market speculation until the June 2015 crash, when the Shanghai Composite Index lost thirty percent of its value within one month.

The question is why, given the growing demand for quality food from China's rapidly increasing middle classes and in its fast-growing urban areas, is agriculture not seen as an economic opportunity? There are many possible explanations, but one is 
extremely simple: plants require land and water to grow.

China has never been a country rich in either land or water. Agriculture has always been highly labour intensive and, as a result, it used to command respect. In Confucian times (from $551 \mathrm{BC}$ to $479 \mathrm{BC}$ ), farmers were second only to scholars in the social hierarchy, above artisans, merchants, and soldiers. Revolutionary mythology elevated farmers (农民often translated as peasants) to the status of labouring heroes, part of a holy trinity alongside workers and soldiers. But political pressure to plant particular crops

(whether or not the land was suitable) and produce bumper harvests forced farmers into over planting, over fertilising, and ultimately depleting already nutrient-poor soil and limited water resources.

In the Maoist past, when things went badly, such as during the three years of mass crop failure and famine from 1959-61, farmers starved. They could not leave the land, though. Internal migration from the rural to the urban areas was severely restricted.

Today, farming is again in crisis, for different reasons. With increased mobility, more young rural people

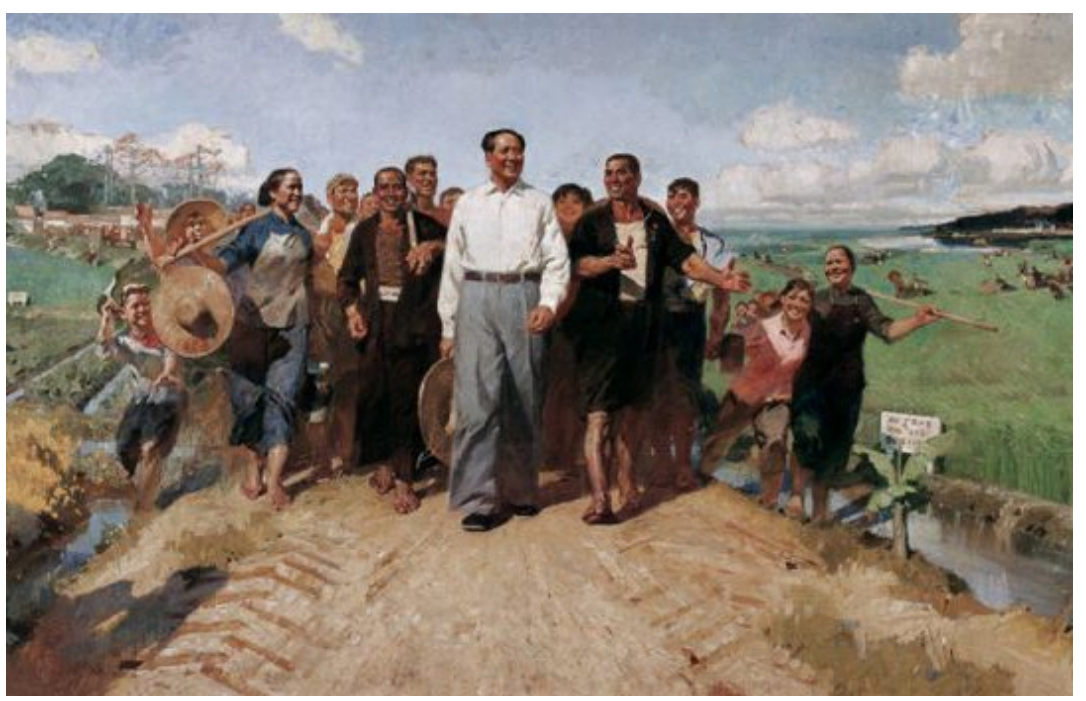

Idyllic Maoist propaganda of labouring heroes and bumper harvests was a far cry from the reality in the Chinese countryside in the 1950 s and 1960 s

Source: upload.m4.cn 
are simply abandoning the fields. Agriculture contributes only nine percent of the country's economic output. (Services, by comparison, make up forty-nine percent). What is more, agricultural land is the main takeover target of aggressively urbanising local governments. Meanwhile, much of the land that is left to grow plants and raise animals, and most of the water available to irrigate it, is poisoned by pollution from chemical fertilisers and pesticides as well as poorly regulated local industry and construction.

A recent national survey of agricultural land suggests that an average of 16.2 percent of all rural land is contaminated. That percentage grows to 19.4 when you exclude grasslands and forests and only consider arable land. The survey is extensive and national, as it is based on samples from about two-thirds of all agricultural land in China. The most common pollutants are inorganic, suggesting that industrial development is the main cause of such pollution. The worst contamination is found in the traditional breadbaskets of the Yangtze Delta and the Pearl River Delta as well as the northeast of the country, all of which have experienced high levels of industrialisation in recent decades.

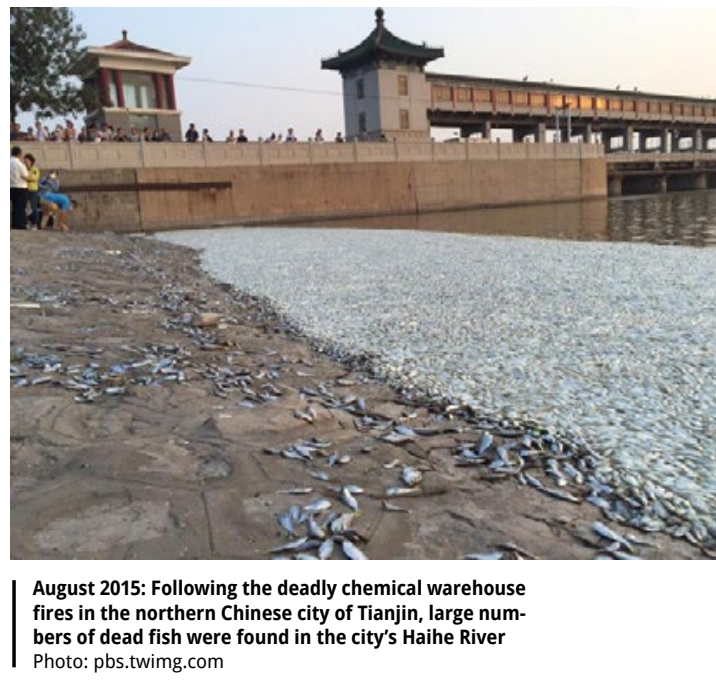

What the survey does not reveal is the potential impact of pollution on the quality of the produce. The release of these numbers, which had long remained a 'state secret', is enough to concern the urban consumers of locally grown agricultural products.

Even more alarming is the quality of China's water, three-quarters of which is used for agriculture. Authorities are working to improve the quality of drinking water in cities to accommodate the growing numbers of people living in urban areas. Yet one estimate suggests that over seventy percent of river water in the country may be unfit for human contact, let alone drinking, and its use in agriculture a danger to public health. In some areas, recorded lead levels in rivers have reached forty-four times the accepted national standards. Officials admit that over sixty percent of underground water is 


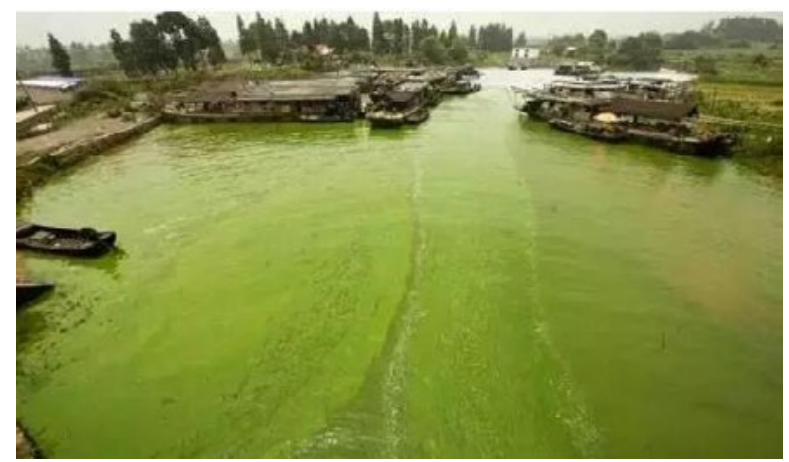

June 2015: Blue-green algae covers Chao Lake in

Anhui province

Source: blog.sina.com.cn

also polluted. The historically uneven water levels of Chinese rivers increase farmers' reliance on wells, heightening the risk of crop contamination from polluted aquifers. Only one-fifth of the water flowing underneath the North China Plain (the area around the lower Yellow River, its tributaries and the land north of it) is deemed safe for human consumption.

The government has launched optimistic campaigns to clean up China's land and water. It hands anti-pollution targets to local cadres, which in reality become one more item in already long to-do lists, often in contradiction with other targets, for example, economic growth, social stability, and urbanisation. Bureaucratic inertia, the size and cost of the clean up, the lack of skills and technology, and the long time frame required for such transformation suggest that things may get worse before they get better.

Agricultural production continues to grow in China, but at an even slower rate than the rest of the economy. A recent report from Deutsche Bank dispels the myth that low productivity can be blamed solely on limited land and water. Comparing China's water and land resources with those of South Korea, DB notices that South Korean farmers have an even greater shortage of natural resources, yet they invest almost six times as much in machinery than their Chinese counterparts, and are more than eighteen times more productive per capita.

The Chinese Academy of Social Sciences believes that Chinese agriculture lags behind that of other world powers, specifically, 108 years behind

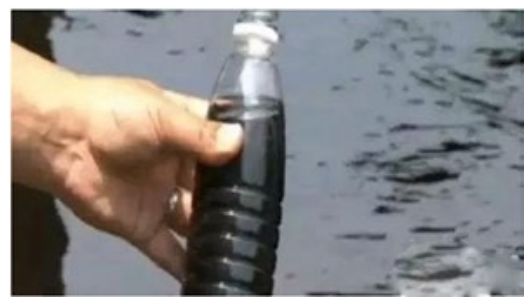

June 2015: Pollution has turned the Lian River in Guangdong black

Source: blog.sina.com.cn 
the US and thirty-six years behind South Korea. An American cow produces four times more milk than a Chinese cow, and the US per hectare production of soy beans is double that of China; China has become the largest soy bean importer in the world. China still produces almost a quarter of the world's food on seven percent of the world's arable land, a remarkable achievement, but one that cannot guarantee self-reliance.

Productivity relies on investment, but the small size of family plots in Chinese villages, limited interest from agribusiness, and collective ownership add up to significantly less investment than is needed. Collective ownership prevents farmers from taking out loans with their land as collateral.

Public ownership of land as a pillar of the socialist market economy at least protects farmers from the vagaries of land speculation (see the China Story Yearbook 2013: Civilising China, Forum 'A New Land Reform', pp.234241). Under the current regime, while farmers don't own the land they work, they enjoy exclusive land use rights for a period of thirty years. In January 2015, the government drafted new guidelines that allow farmers in thirtythree counties to trade these land use

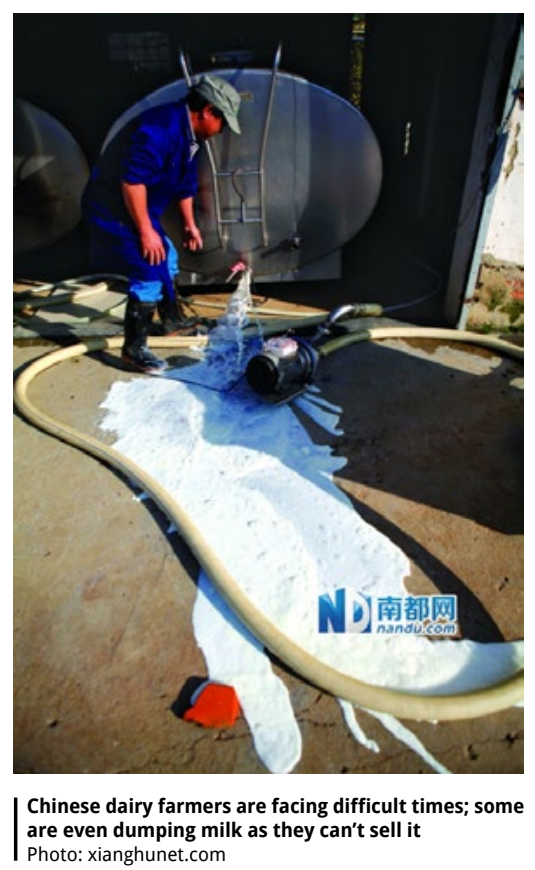

rights. Previously, such rights were inalienable. There are still significant limitations on the trade: villages will be allowed to trade land only where it has been clearly redefined as 'nonagricultural' and where collectives have adopted a shareholding structure for ownership. The pilot areas are scattered across every single province in the country, including all provinciallevel municipalities.

The experiment was inspired by Chongqing's experiment with land tickets' beginning in 2010 to facilitate the expropriation of land for urbanisation. The local government provided 'land tickets' to collectives that allowed them to trade available land on a limited market. Huang Qifan 黄奇帆, the 


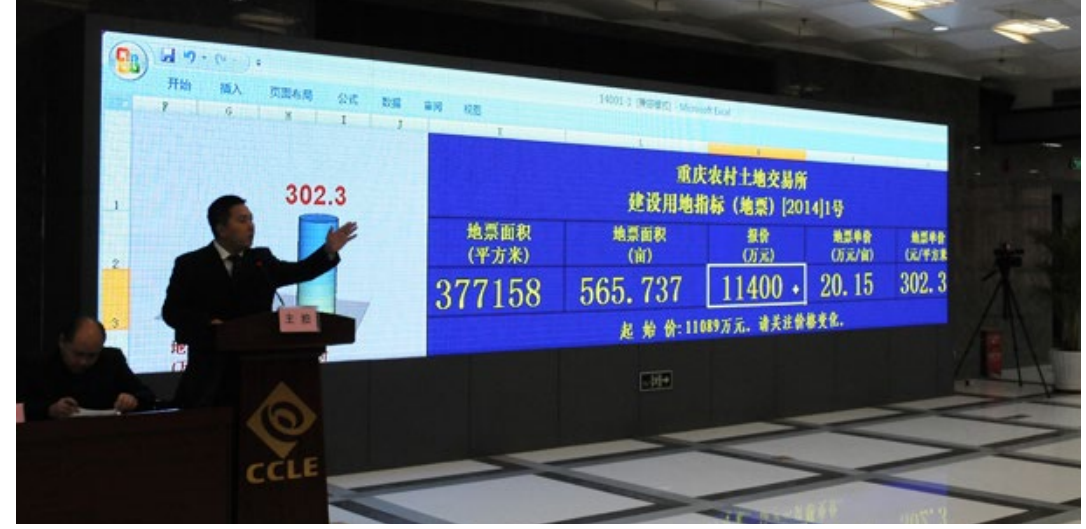

Chongqing's experiment with 'land tickets'

Photo: cq.xinhuanet.com

mayor of Chongqing, recently suggested that land use rights valued at more than RMB 30 billion have changed hands since 2010 thanks to this system-and that Chongqing (which has eighteen million farmers and 300,000 hectares of rural land) experienced no loss of farmland in the process. The state's argument is that urbanisation leads to more efficient management of land.

To supplement the pilot scheme, the government is also carrying out a survey of 'permanent farmland'high-quality agricultural land that should never be converted. Previously, it had spoken of drawing a 'red line' under the loss of arable land to pur-

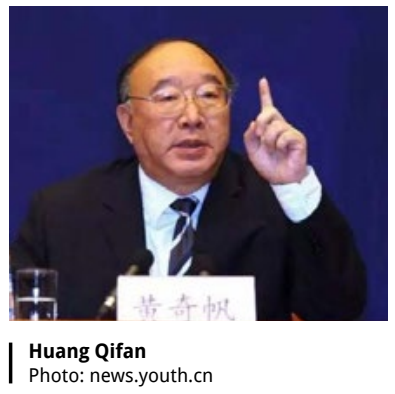

poses other than agriculture so that there would always be at least 120 million hectares available for farming. The need to preserve agricultural land and the trade in it are in obvious contradiction, as the most immediately rewarding way of using land is to convert it to industrial or construction use.

It is difficult to see a solution to China's farming problems, or a successful way forward for its agriculture. Changing consumption habits in the cities, however, suggest a way forward for growers in search of higher returns from small plots. Years of continuous and high profile food scandals have generated a greater demand among middle-class and wealthy consumers for organic and premium agricultural products. The amount of certified organic produce in China has tripled since 2007, but still only represents about one percent of total national production.

For the moment, organic products are still easier to source from overseas. Ever since the tainted milk 
and baby formula scandals of 2008 and beyond, foreign dairy farms have been high on the list of acquisition targets for Chinese investors. The assumption is that accessing existing production facilities overseas, even at a premium (Chinese investors recently ploughed US $\$ 43$ billion into a Swiss agricultural company) is a better deal than trying to convert China's contaminated soil to the level of purity required for organic production.

Australia, which possesses over half of all the certified organic land in the world, remains the third largest exporter of agricultural products to China, after the US and Brazil. Its export of dairy products to China has grown threefold from 2007. Demand for organic Australian produce from overseas markets including China is already forty percent higher than what Australian farms can supply. While Chinese companies own only one percent of all Australian agricultural land, China offers Australia's farmers a fast-growing export market for quality food. All large agricultural producers have benefited from China's increasing hunger for quality produce, with the US exporting about twenty-six billion dollars worth of agricultural goods to China (now its top destination for agricultural exports).
In Australia, the sale of the nation's oldest and largest dairy farm, Tasmania's Van Diemen's Land Company to Chinese investors generated heated discussion about whether the sale was in Australia's 'national interest'. The ratification of a bilateral free trade agreement in December means there are likely to be even greater efforts by Chinese investors to acquire agricultural assets that produce the goods that are increasing greater Chinese demand for the goods themselves. The Chinese urban consumer is both wealthy enough and eager enough to pay premium prices on quality products and, however the free-trade agreement plays out, Australian organic farmers, in particular, are likely to do very well in the coming years.

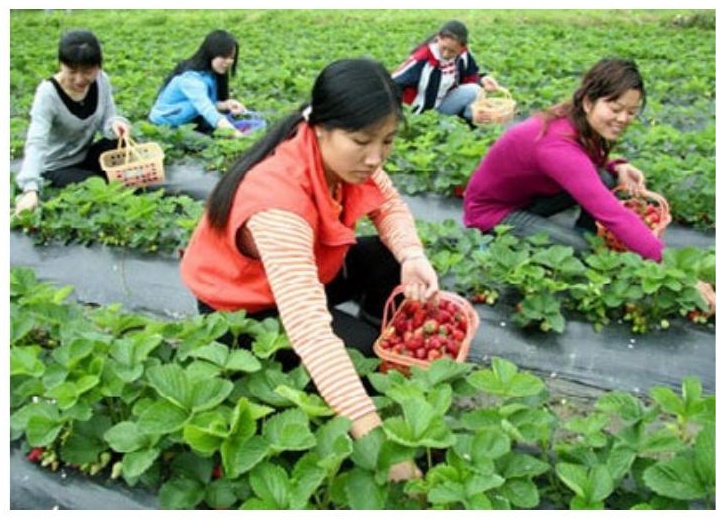

Demand for organic farming in China is growing Photo: mt.sohu.com 
This text is taken from China Story Yearbook 2015: Pollution, edited by Gloria Davies, Jeremy Goldkorn and Luigi Tomba, published 2016 by ANU Press, The Australian National University, Canberra, Australia. 